\title{
Pemanfaatan Aplikasi Sebagai Media Bantu Edukasi Agama Islam Untuk Anak Usia Dini
}

\author{
Guntoro Barovih*1, Eka Prasetya Adhy Sugara ${ }^{2}$ Nurussama $^{3}$ \\ ${ }^{1}$ Program Studi Teknik Informatika, STMIK PalComTech \\ ${ }^{2}$ Program Studi Desain Komunikasi Visual, Politeknik PalComTech \\ ${ }^{3}$ Program Studi Akutansi, Politeknik PalComTech \\ e-mail : guntoro@palcomtech.ac.id, eka p@palcomtech.ac.id, nurussama@palcomtech.ac.id
}

\begin{abstract}
The use of technology and software in learning activities is very important, because it can help teachers deliver learning materials and encourage students' interest in learning. TPA Darul Quddus Unit 232 is a partner in Community Partnership Program (PKM) activities, where teaching and learning activities still use conventional learning methods without using technology and learning software so that it feels monotonous and boring for alpha generation children. The purpose of this community service is to study the use of technology in teaching and learning activities. This service activity method is carried out by direct observation, interviews and pre-test and post-test. The output of this community service activity resulted in 2 desktop-based and mobile-based learning applications, 1 multimedia application, and 1 TPA governance management application. The results of the pre-test and post-test measurements are to increase the ability, mastery and use of technology and software in teaching and learning activities.
\end{abstract}

Keywords: Technology, application, educational media, early age,

\begin{abstract}
Abstrak
Penggunaan teknologi dalam kegiatan belajar menjadi sangat penting, karena pemanfaatan teknologi, perangkat lunak dalam kegiatan belajar sangat membantu para pengajar dalam menyampaikan materi pembelajaran serta mendorong minat siswa dalam belajar. TPA Darul Quddus unit 232 merupakan mitra dalam kegiatan PKM ini, dimana dalam kegiatan belajar dan mengajarnya masih menggunakan cara pembelajaran yang konvensional tanpa memanfaatkan teknologi dan perangkat lunak pembelajaran sehingga terkesan monoton dan membosankan bagi anak-anak generasi alpha. Tujuan dari pengabdian ini adalah mengedukasikan penggunaan teknologi dalam kegiatan belajar mengajar. Metode pelaksanaan pengabdian ini dilakukan dengan cara pengamatan langsung pada tenaga pengajar dan siswa, wawancara dan pengujian pre test dan post test pada tenaga pengajar. Luaran dari pengabdian ini menghasilkan 2 aplikasi pembelajaran berbasis desktop dan mobile, 1 aplikasi multimedia dan 1 aplikasi manajemen tata kelola TPA. Hasil pengukuran pre test dan post test ternjadi peningkatan kemampuan, penguasaan dan pemanfaatan teknologi dan perangkat lunak dalam kegiatan belajar dan mengajar.
\end{abstract}

Kata kunci-Teknologi, Aplikasi, media edukasi, Usia Dini

\section{PENDAHULUAN}

Teknologi sekarang ini berkembang dengan sangat pesat dan sudah menjalar ke berbagai sektor kehidupan manusia dengan tujuan untuk membantu kegiatan manusia baik dalam bekerja maupun dalam proses belajar. berbagai macam bentuk teknologi diciptakan untuk mempermudah dalam penggunaan dan fleksibel bisa digunakan dimana saja dan dipergunakan oleh siapa saja. Karena perkembangan teknologi yang masif, tentu saja ini berdampak tidak baik dan berakibat pada ketergantungan pada gawai jika anak-anak secara mandiri menggunakan teknologi tersebut tanpa ada pendampingan dari orang tua, atau orang tua yang membiarkan anak-anak untuk menggunakan gawai dalam bentuk pola asuh, dimana (Mufaro'ah et al., 2019) menyebutkan bahwa sebesar $88,31 \%$ orang tua masih menggunakan pola asuh yang permisif dimana orang tua memberikan izin bagi anak untuk menggunakan gawai dalam pengasuhan dan tanpa pembatasan. Serta masih kecilnya kesadaran orang tua dalam melakukan pola asuh yang demokratis dimana pola asuh yang menggunakan gadget dengan pendampingan, pembatasan 
serta edukasi dalam penggunaannya. Pemanfaatan teknologi sekarang ini banyak di dominasi oleh generasi $\mathrm{x}$, generasi milenial, generasi $\mathrm{z}$ dan generasi Alfa yang diprediksikan akan mendominasi penggunaan teknologi di masa yang akan mendatang jika dilihat rentang usia < 5-9 tahun, hal ini membuktikan bahwa perkembangan teknologi sudah tidak bisa di bentung sudah masuk ke berbagai usia dalam hal penggunaannya(Databoks, n.d.; Maharrani, n.d.).

Masifnya perkembangan teknologi juga berdampak pada banyaknya para peneliti dan pengembang perangkat lunak membuat aplikasi-aplikasi yang bisa membantu anak-anak dalam belajar khususnya untuk anak-anak usia dini dimana usia ini adalah periode keemasan anak-anak mendapatkan informasi yang bermanfaat dan mendidik dengan pola bermain seperti dunianya anak-anak. Berbagai bentuk aplikasi yang diciptakan mulai dari bentuk game edukasi yang berisikan materi pelajaran mengenal bentuk rupa binatang, mewarnai serta mengenal hurufhuruf alfabet dalam bentuk animasi yang ditujukan pada anak-anak usia 3-6 tahun dengan tujuan untuk mengasah daya ingat, kreatif dan imajinatif serta menumbuhkan seluruh kemampuan positif anak yang bisa mendukung tumbuh kembang anak(Putra et al., 2016),(Simbolon et al., 2018).

Pada penelitian lainnya pemanfaatan teknologi dalam hal ini penggunaan aplikasi edukasi juga digunakan untuk mengedukasi anak-anak mengenal kebudayaan bangsa pada usia dini dengan cara mengenalkan pakaian adat nusantara dari berbagai provinsi dan kebudayaan dalam bentuk puzzel yang diharapkan mampu mengasah atau meningkatkan daya ingat dan logika anakanak di periode keemasan serta tidak menutup kemungkinan bisa digunakan di semua tingkatan umur (Agustina and Wahyudi, 2015). Tidak hanya sebatas aplikasi yang terimplementasi pada gawai atau gadget saja, media edukasi untuk meningkatkan kemampuan anak pada periode keemasannya juga diterapkan dalam bentuk multimedia yang edukatif dalam bentuk permainan mencari perbedaan suatu bentu untuk melatih ketelitian, kejelian dan pola pikir anak dalam mengambil keputusan pada sautu kondisi(Halidah, 2006). Selain bentuk pengetahuan umum dan pengenalan karakter hewan serta permainan daya ingat, banyak peneliti juga mengembangkan aplikasi edukasi yang fokus pada ilmu agama untuk membangun karakter anak agar lebih mengenal agama dan dasar agama serta merangsang motorik anak walaupun dimulai dari pengenalan huruf-huruf hijaiyah(Zahrotun et al., 2015).

TPA Darul Quddus merupakan Lembaga pendidikan nonformal jenis keagamaan Agama Islam, bertujuan untuk memberikan pengajaran al Qur'an dan memahami dasar dinul islam sejak usia dini. Dalam kegiatan pengabdian yang penulis lakukan memanfaatkan perangkat lunak edukasi yang berbasiskan desktop application, mobile application dan multimedia sebagai media pembelajaran yang berfokus pada pengenalan dasar-dasar agama islam, doa sehari-hari dan mengenal asmaul husnah melalui teknik mewarnai dengan harapan mampu meningkatkan pemahaman agama islam, daya ingat anak serta motorik anak.

\section{METODE}

Metode yang dilakukan dalam kegiatan Program Kemitraan Masyarakat (PkM) yang dilakukan di Taman Pendidikan Al Qur'an Darul Quddus unit 232 Palembang dijabarkan dalam bentuk diagram seperti tampak pada gambar 1. 


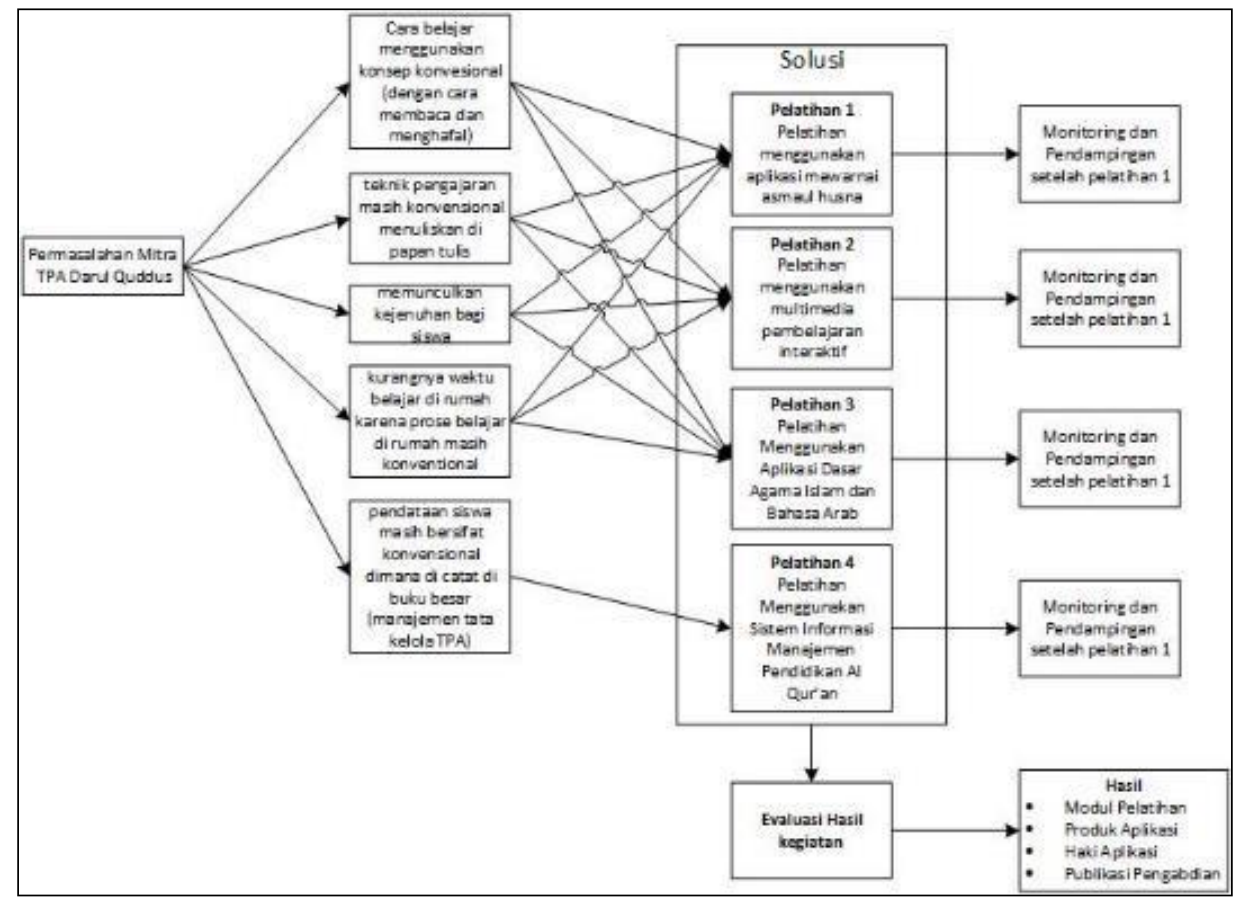

Gambar 1. Metode Pelaksanaan PkM

\section{1 Identifikasi Masalah}

Hal pertama yang dilakukan dalam kegiatan PkM ini adalah melakukan analisis permasalahan yang terjadi di lokasi dalam hal ini adalah Mitra TPA Darul Quddus, dimana ada beberapa point yang bisa disimpulkan yaitu:

1. Cara belajar dan teknik mengajar yang dirasa masih menggunakan konsep konvensional yaitu dengan cara menghafal dan menulis di papan tulis, munculnya kejenuhan bagi anak-anak dalam kegiatan belajar menggunakan cara konvensional dikarenakan anak-anak pada zaman sekarang atau biasa disebut sebagai anak-anak generasi alfa yang sudah terbiasa dengan halhal menarik dalam kegiatan belajar dengan menggunakan bantuan teknologi. Karena anakanak pada zaman sekarang dilahirkan dari ayah dan ibu dari generasi sebelumnya yaitu generasi $\mathrm{Y}$ dan $\mathrm{Z}$ yang sudah dekat dengan perkembangan teknologi(Adam, 2017; Putri, 2016). Maka dari itu diciptakanlah teknologi dalam bentuk perangkat lunak guna membantu kegiatan proses belajar yang lebih menarik dan dinamis. Untuk itu pembelajaran dengan menggunakan teknologi yang digunakan perlu diawasi dan di bimbing serta di dampingi oleh orang tua.

2. Masih kurangnya kemampuan para tenaga pengajar dalam menggunakan perangkat teknologi.

3. Permasalahan yang kedua adalah manajemen tata kelola siswa dan tenaga pengajar yang dirasa perlu dilakukan perubahan sehingga bisa termanajemen lebih baik lagi, maka dari itu digunakanlah teknologi dalam bentuk sistem informasi manajemen dalam membantu memanajemen tat kelola TPA Darul Quddus. 

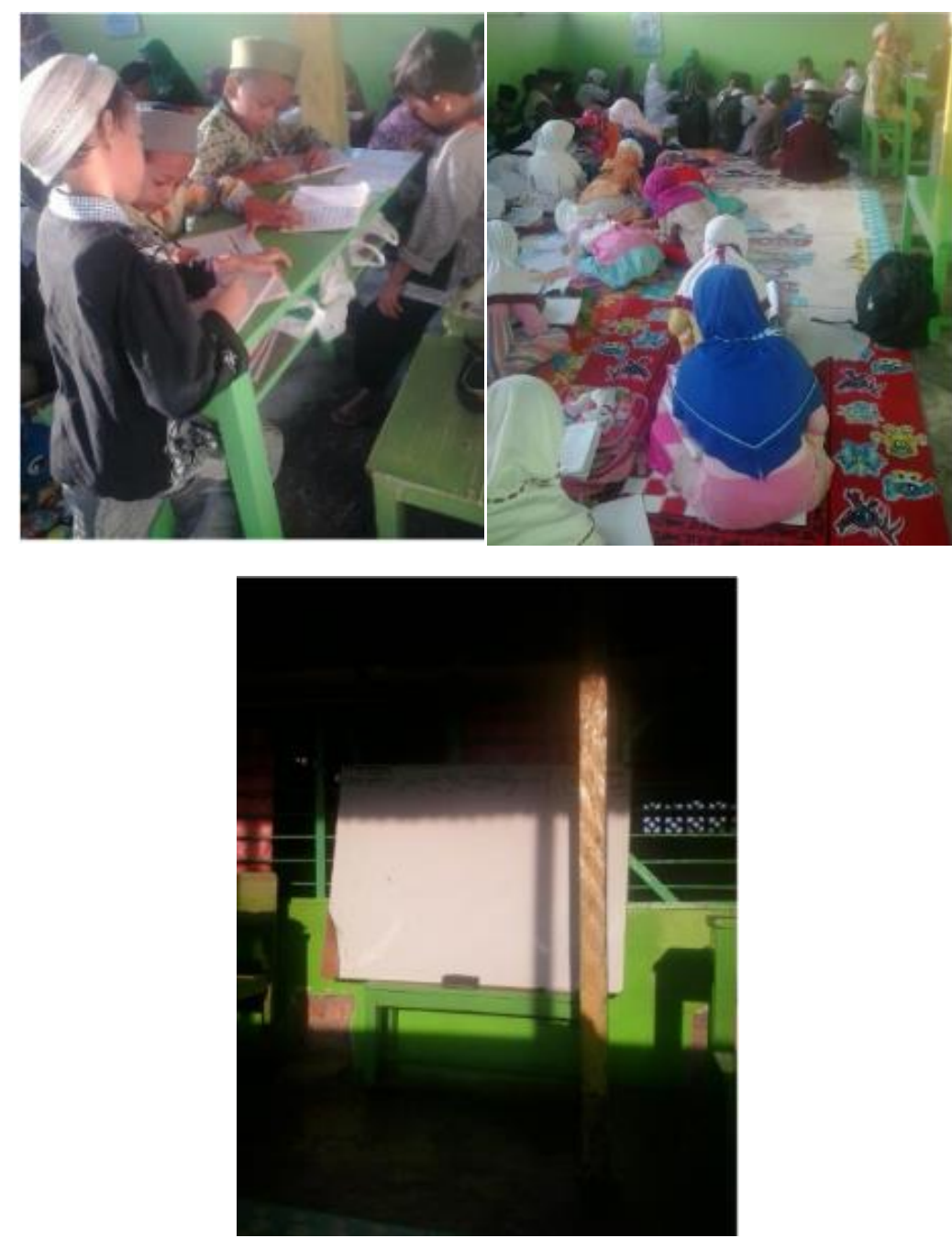

Gambar 2 kegiatan proses belajar dan alat peraga dalam kegiatan mengajar di TPA Darul Quddus

\section{HASIL DAN PEMBAHASAN}

\section{1 Solusi}

Dari permasalahan tersebut, maka yang dilakukan dalam kegiatan ini untuk mendorong proses belajar yang lebih menarik dan dinamis adalah membuat suatu produk multi media dan perangkat lunak untuk mendorong animo siswa dalam belajar dan memperbanyak waktu belajar dengan cara bermain, menonton animasi dan bermain sambil belajar bersama orang tua di rumah. Serta membangun suatu aplikasi manajemen tata kelola yang bisa digunakan oleh TPA Darul Quddus dalam mengelola data siswa, tenaga pengajar dan manajemen keuangan. 

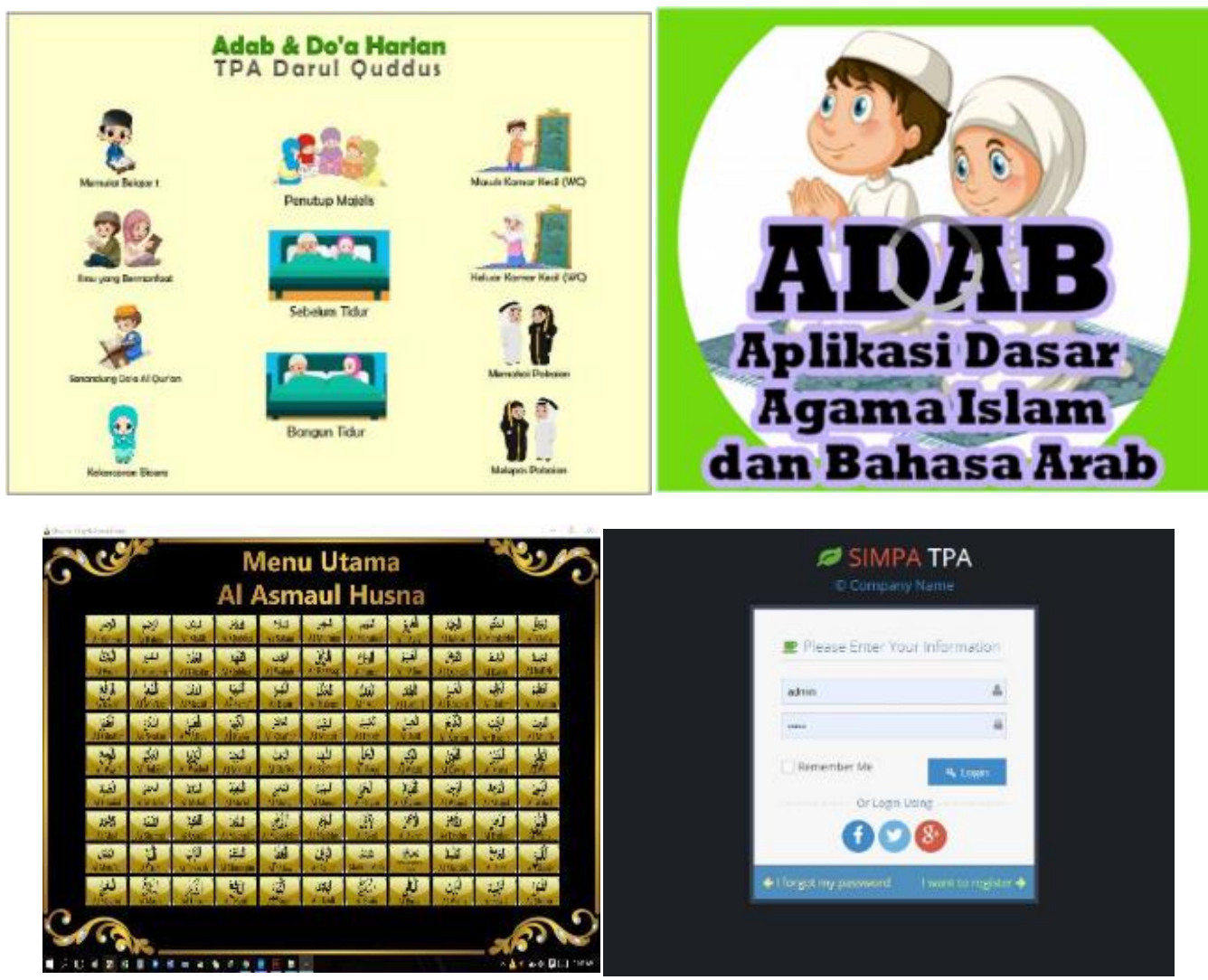

Gambar 3. Aplikasi Pembelajaran interaktif Multi media Pembelajaran, ADAB dan mewarnai Asmaul Husnah. Sistem Informasi Manajemen Pendidikan Al Qur'an (SIMPA TPA)

\section{2 Pelatihan}

Setelah dilakukan pemetaan permasalahan dan solusi apa saja yang bisa digunakan. Maka, tahap selanjutnya yang dilakukan adalah membangun aplikasi yang akan digunakan dalam kegiatan belajar di TPA Darul Quddus. Dari pemetaan permasalahan didapatkan ada 3 aplikasi edukasi yang bisa gunakan yaitu antara lain aplikasi mewarnai asmaul husnah yang berbasiskan pada perangkat komputer, aplikasi belajar dasar agama islam dan bahasa arab yang berbasiskan pada perangkat smartphone berplatform android yang bisa digunakan dalam kegiatan belajar baik di TPA Darul Quddus ataupun di rumah bersama orang tua dan multimedia pembejaran berupa video animasi. Dan 1 aplikasi sistem informasi manajemen yang berbasiskan web sehingga mudah untuk di akses dimana saja. Keempat aplikasi ini diedukasikan kepada para ustadz/ustadzah sebagai tenaga pengajar dan pengguna sistem informasi manajemen. 


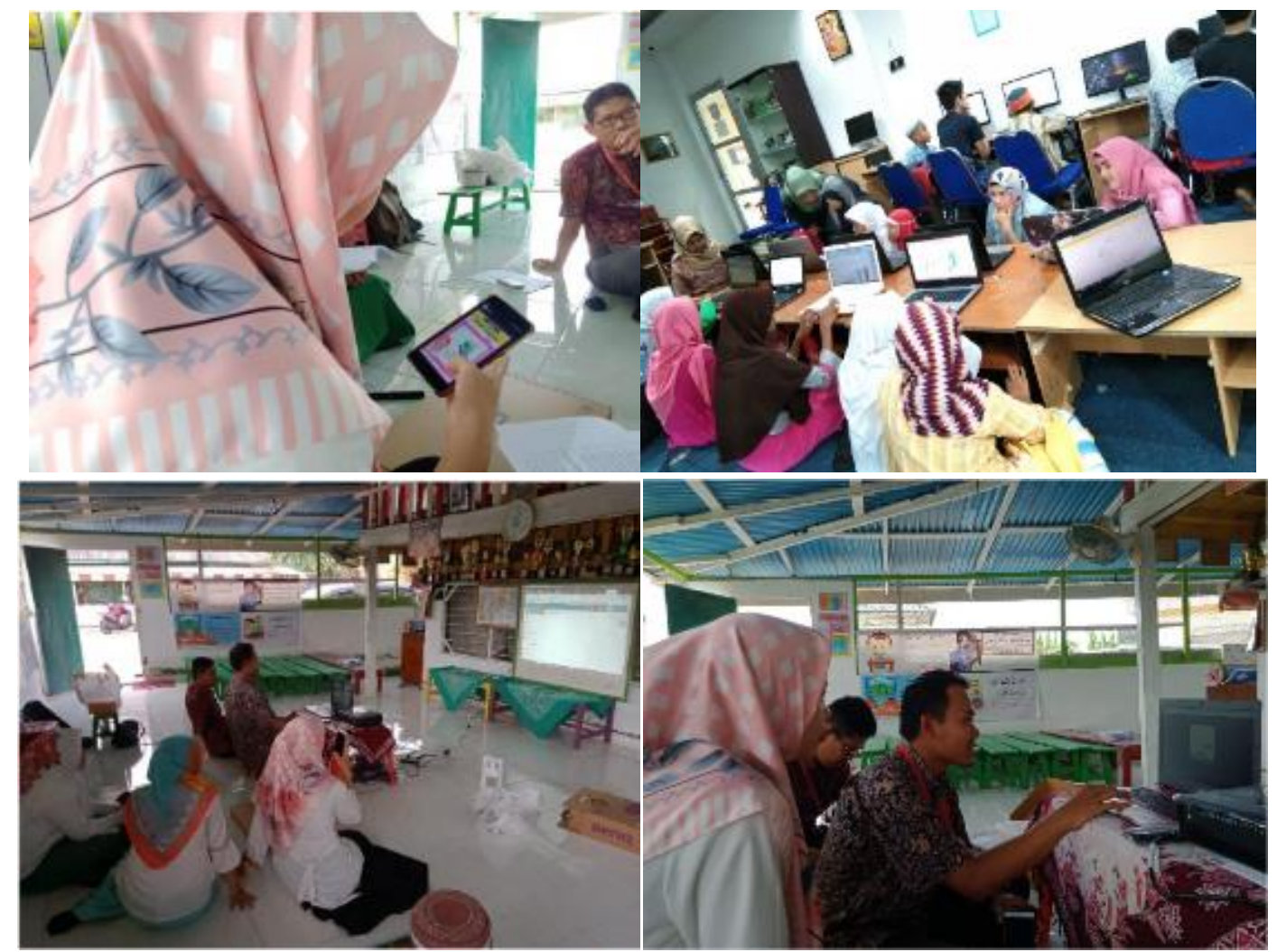

Gambar 4. Pelatihan penggunaan aplikasi pembelajaran dan sistem informasi manajemen TPA

\section{3. Sosialisasi}

Aplikasi yang sudah di bangun kemudian diedukasikan kepada tenaga pengajar. Aplikasi pembelajaran disosialisasikan kepada para siswa dan dipraktikan oleh para siswa didampingi oleh tenaga pengajar untuk melihat animo, antusias siswa dan ketertarikan siswa TPA menggunakan teknologi dalam bentuk aplikasi dalam kegiatan belajar.
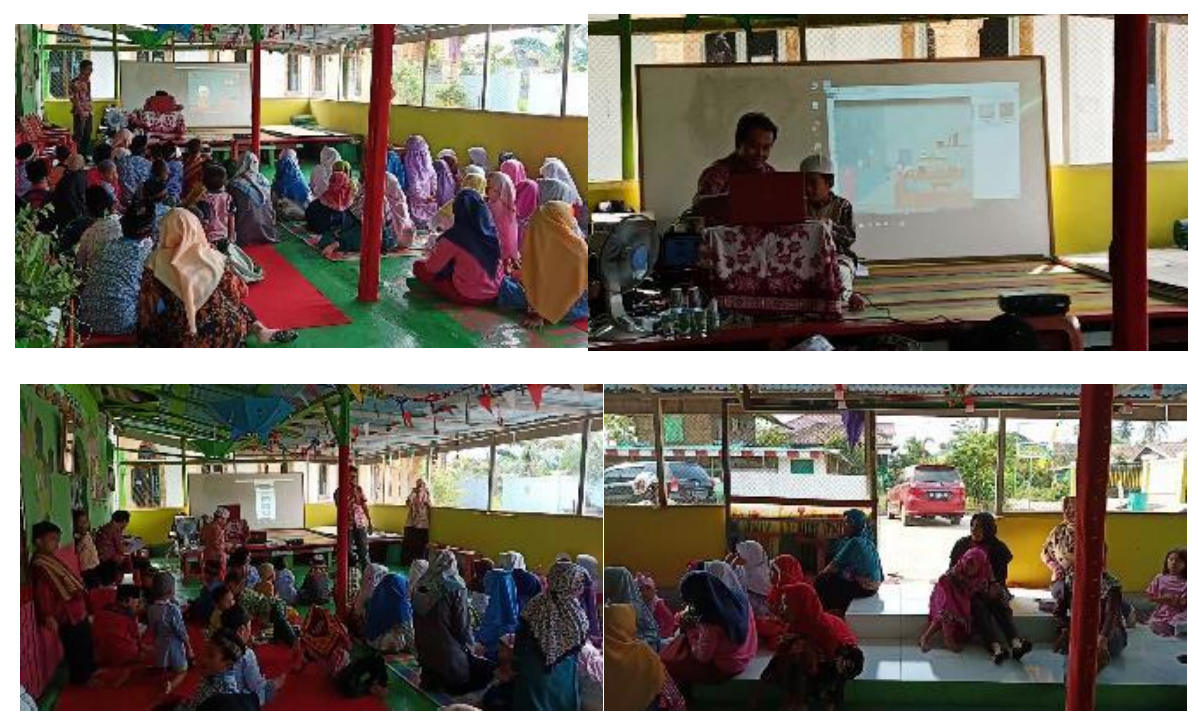

Gambar 5. Sosialisasi Penggunaan aplikasi media Pembelajaran dalam kegiatan belajar di TPA Darul Quddus 


\section{4. Monitoring Penggunaan Perangkat Teknologi}

Pada tahapn ini melihat keluesan tenaga pengajar menggunakan teknologi dan animo siswa dalam kegiatan belajar dengan menggunakan alat bantu teknologi yang telah diedukasikan sebelumnya. Dengan cara melakukan pengamatan langsung dan penilaian pre test dan post test. Kemudian dari data pengamatan langsung, data pre test dan post test diolah untuk mendapatkan hasil yang diharapkan.
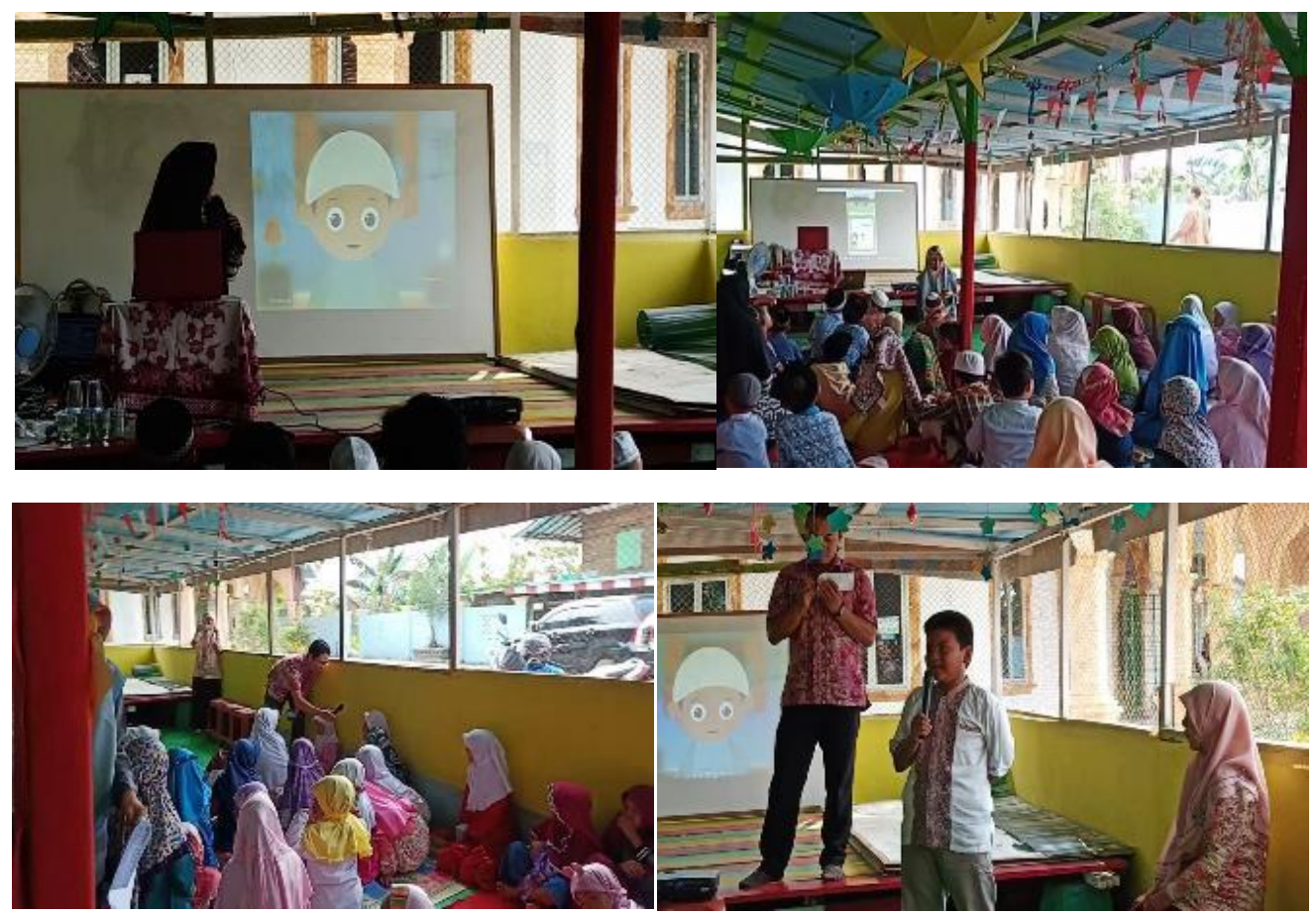

Gambar 6. Monitoring penggunaan perangkat teknologi pengamatan langsung animo siswa dalam kegiatan belajar

\section{5. Pengukuran Penguasaan Teknologi Pembelajaran}

Berdasarkan hasil pre test, post test yang digunakan untuk mengukur pemahaman dan kemampuan para tenaga pengajar ( ustadz dan ustadzah) dalam penggunaan teknologi pada kegiatan mengajar di TPA Darul Quddus, memperlihatkan terjadinya peningkatan kemampuan pengetahuan dan penguasaan teknologi dari masing-masing ustadz dan ustadzah dalam kegiatan belajar dan mengajar berlangsung. Peningkatan tersebut bisa dilihat pada grafik pre test dan post test pada gambar 7 .

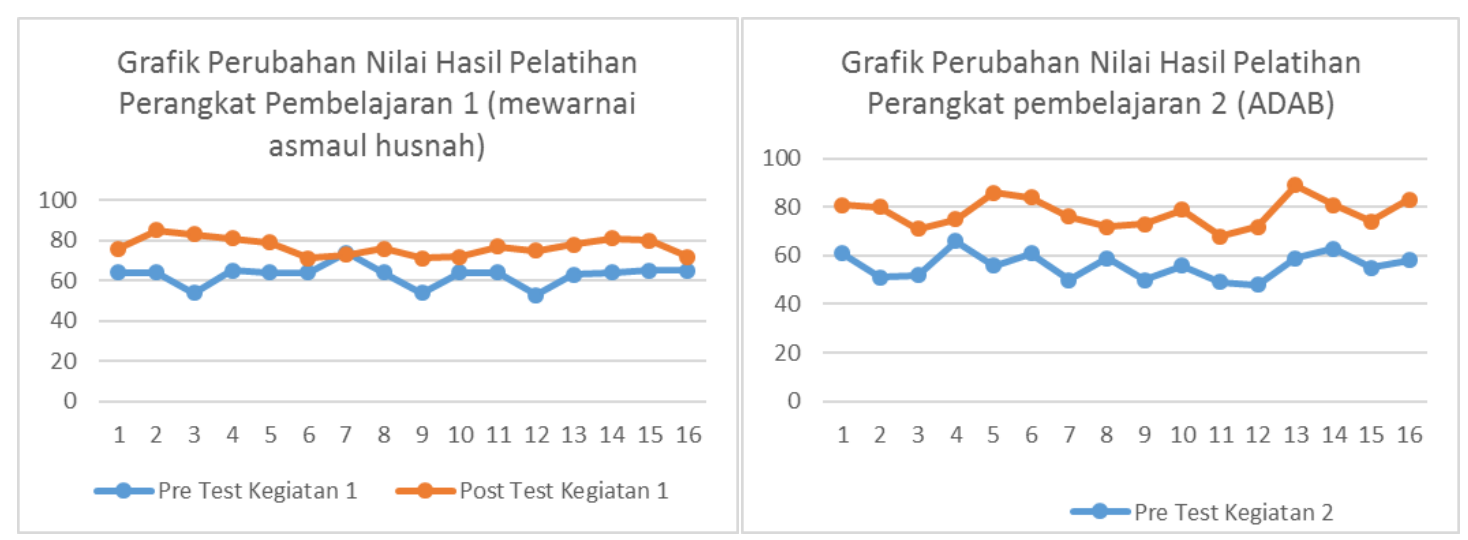




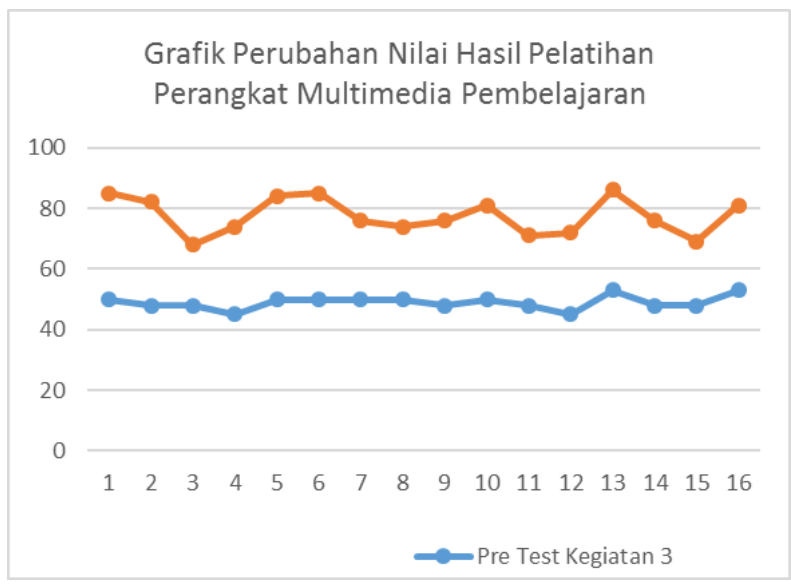

Gambar 7. Hasil rekapitulasi pre test dan post test pengetahuan dan penguasaan teknologi pembelajaran

Berdasarkan dari hasil pre test yang ditujukan kepada tenaga pengajar untuk mengetahui pemahaman teknologi pembelajaran khususnya pada platform yang berbeda didapatkan bahwa pada hasil pre test pada aplikasi pembelajaran yang pertama (mewarnai asmaul husnah) didapatkan hasil pre test sudah cukup baik dimana nilai tertinggi yang didapatkan adalah 70 sedangkan nilai terendah kurang dari 60 berjumlah 3 orang hal ini memperlihatkan para tenaga pengajar sudah banyak yang mengetahui teknologi pembelajaran berbasis desktop dengan cukup baik. Aplikasi kedua nilai pre test tertinggi 69 sedangkan nilai terendah 50 dari hasil ini memperlihatkan banyak yang mengetahui teknologi pembelajaran berbasiskan android secara konsumtif tetapi tidak mengetahui bagaimana cara penggunaan secara edukatif. Aplikasi ketiga multimedia pembelajaran dari hasil pre test memperlihatkan pemahaman bahwa multimedia hanya digunakan sebagai media tontonan yang tidak bisa digunakan secara interaktif dan edukatif.

Setelah dilakukan sosialisasi, pelatihan dan pendampingan kepada tenaga pengajar pada TPA Darul Quddus dalam penggunaan dan pemanfaatan media pembelajaran dari berbagai platform aplikasi, kemudia peneliti melakukan pengujian ulang dalam bentuk post test untuk melihat apakah terdapat peningkatan pemahaman dan pemanfaatan teknologi dalam kegiatan belajar dan mengajar berlangsung. Dari hasil pengujian post test didapatkan terjadi peningkatan yang sangat baik dari setiap tenaga pendidik dalam memahami bentuk perangkat teknologi pembelajaran, cara memanfaatkannya dalam kegiatan belajar dan mengajar, serta memahami cara mengoprasikannnya dan mengintraksikan teknologi bersama siswa dalam kegiatan belajar.

\section{KESIMPULAN}

Berdasarkan uraian kegiatan pengabdian kepada masyarakat yang telah dilaksanakan pada TPA Darul Quddus, dapat disumpulkan antara lain :

1. Perangkat lunak teknologi informasi membantu para ustadz dan ustadzah selaku tenaga pengajar dalam menyampaikan materi belajar kepada para siswa.

2. Meningkatnya kemampuan dan pengetahuan para tenaga pengajar (ustadz dan ustadzah) dalam memanfaatkan teknologi sebagai alat bantu dan alat peraga dalam kegiatan belajar dan mengajar.

3. Meningkatnya minat siswa dalam belajar di TPA meningkat karena kegiatan belajar menjadi interaktif dan menyenangkan. 
4. Perangkat lunak yang dikembangkan juga bisa diadaptasikan di rumah sebagai alat atau media belajar bagi siswa di rumah.

5. Terdapat kekurangan pada aplikasi mewarnai asmaul husnah, dimana garis tepi pada gambar masih terlihat tipis dan samar sehingga menyulitkan siswa untuk melihat garis tepi yang di tampilkan. serta tidak bisa membuat kaligrafi di dalamnya hanya fokus pada kegiatan mewarnai saja.

6. Terdapat kekurangan pada aplikasi adab dimana materi yang ditampilkan hanya dalam bentuk gambar tidak ada nada suara pembacaan.

Terdapat kekurangan pada multimedia pembelajaran dimana dari hasil pengamatan langsung kepada siswa didapatkan bahwa durasinya pendek, animasi yang ditampilkan masih kaku.

\section{UCAPAN TERIMA KASIH}

Penulis mengucapkan terima kasih kepada kementerian Ristek Dikti yang telah memberi dukungan Pendanaan dalam kegiatan pengabdian kepada masyarakat yang peneliti lakukan, terima kasih kepada Lembaga Penelitian dan Pengabdian Masyarakat (LPPM) STMIK dan Politeknik Palcomtech yang telah mendukung kegiatan ini. Terima kasih kepada TPA Darul Quddus unit 232 yang telah bersedia menjadi mitra dalam kegiatan pengabdian kepada masyarakat ini dan bersedia meluangkan waktu dan tempat untuk melaksanakan kegiatan ini.

\section{DAFTAR PUSTAKA}

Adam, A., 2017. Habis Milenial dan Generasi Z, Terbitlah Generasi Alfa [WWW Document]. tirto.id. URL https://tirto.id/habis-milenial-dan-generasi-z-terbitlah-generasi-alfa-cnEs (accessed 9.17.19).

Agustina, C., Wahyudi, T., 2015. Aplikasi Game Pendidikan Berbasis Android Untuk Memperkenalkan Pakaian Adat Indonesia. IJSE - Indones. J. Softw. Eng. 1, 1-8.

Databoks, n.d. Media Digital Membunuh Media Konvensional? [WWW Document]. 2018. URL https://databoks.katadata.co.id/datapublish/2018/02/18/media-digital-membunuhmedia-konvensional (accessed 9.18.19).

Halidah, I., 2006. Multimedia Untuk Anak Usia Dini Israini Halidah. J. Sist. dan Teknol. Inf.

Maharrani, A., n.d. Generasi Z, pengguna internet terbesar di Indonesia [WWW Document]. 2019. URL https://beritagar.id/artikel/berita/generasi-z-pengguna-internet-terbesar-diindonesia (accessed 9.18.19).

Mufaro'ah, Sumarni, T., Sofiani, I.K., 2019. Pengaruh Gawai Dalam Pola Asuh Orang Tua Terhadap Anak Usia Dini ( Studi Kasus Orang Tua dari Anak Usia 5 Tahun di TKIT Ibu Harapan Kecamatan Bengkalis ). Al-Ishlah J. Pendidik. 11, 96-113.

Putra, D.W.; Nugroho, A.P.;, Puspitarini, E.W., 2016. Game Edukasi Berbasis Android Sebagai Media Pembelajaran Untuk Anak Usia Dini. JIMP - J. Inform. Merdeka Pasuruan 1, 46-58.

Putri, E., 2016. Generasi X, Y, Z, Alpha, Baby Boomers: Termasuk Yang Manakah Kamu? [WWW Document]. magazine.banananina.co.id. URL https://magazine.banananina.co.id/generasix-y-z-alpha-baby-boomers-termasuk-yang-manakah-kamu/ (accessed 9.17.19).

Simbolon, F.A., Guntur, S., Erwin, P., Sihotang, H.T., 2018. Sebagai Media Pengenalan Bagi Anak Usia Dini Dengan Metode Computer Based Instruction ( CBI ). J. Inform. Pelita Nusant. 3, 2331.

Zahrotun, L., Soleh, Z.R., Informatika, T., Dahlan, U.A., Prof, J., Sh, S., 2015. Media Pembelajaran Pengenalan Huruf Hijaiyah Untuk Anak Usia Dini 2-3 Tahun. J. Telemat. 12, 75-81. 